\title{
OH-Radical Oxidation of Lung Surfactant Protein B on Aqueous Surfaces
}

\author{
Shinichi Enami*,1 and Agustín J. Colussi ${ }^{2}$ \\ ${ }^{1}$ National Institute for Environmental Studies, 16-2 Onogawa, Tsukuba, Ibaraki 305-8506, Japan \\ ${ }^{2}$ Linde Center for Global Environmental Science, California Institute of Technology, California 91125, U.S.A.
}

\begin{abstract}
Air pollutants generate reactive oxygen species on lung surfaces. Here we report how hydroxyl radicals $(\cdot \mathrm{OH})$ injected on the surface of water react with $\mathrm{SP}_{-\mathrm{B}_{1-25}}$, a 25-residue polypeptide surrogate of human lung surfactant protein $\mathrm{B}$. Our experiments consist of intersecting microjets of aqueous $\mathrm{SP}_{-\mathrm{B}_{1-25}}$ solutions with $\mathrm{O}_{3} / \mathrm{O}_{2} / \mathrm{H}_{2} \mathrm{O} / \mathrm{N}_{2}(\mathrm{~g})$ gas streams that are photolyzed into $\cdot \mathrm{OH}(\mathrm{g})$ in situ by $266 \mathrm{~nm}$ laser nanosecond pulses. Surface-sensitive mass spectrometry enables us to monitor the prompt $(<10 \mu \mathrm{s})$ and simultaneous formation of primary $\mathrm{O}_{n}$-containing products/intermediates $(n \leq 5)$ triggered by the reaction of $\cdot \mathrm{OH}$ with interfacial $\mathrm{SP}-\mathrm{B}_{1-25}$. We found that $\mathrm{O}$-atoms from both $\mathrm{O}_{3}$ and $\cdot \mathrm{OH}$ are incorporated into the reactive cysteine $\mathrm{Cys}_{8}$ and $\mathrm{Cys}_{11}$ and tryptophan Trp ${ }_{9}$ components of the hydrophobic N-terminus of SP-B $\mathrm{B}_{1-25}$ that lies at the topmost layers of the air-liquid interface. Remarkably, these processes are initiated by $\cdot \mathrm{OH}$ additions rather than by $\mathrm{H}$-atom abstractions from $\mathrm{S}-\mathrm{H}, \mathrm{C}-\mathrm{H}$, or $\mathrm{N}-\mathrm{H}$ groups. By increasing the hydrophilicity of the N-terminus region of SP- $\mathrm{B}_{1-25}$, these transformations will impair its role as a surfactant.
\end{abstract}

Copyright (c) 2018 Shinichi Enami and Agustín J. Colussi. This is an open access article distributed under the terms of Creative Commons Attribution License, which permits use, distribution, and reproduction in any medium, provided the original work is properly cited and is not used for commercial purposes.

Please cite this article as: Mass Spectrom (Tokyo) 2018; 7(2): S0077

Keywords: air pollution, lung surfactant, reactive oxygen species, interfacial reaction, protein

(Received August 21, 2018; Accepted October 11, 2018)

\section{INTRODUCTION}

Human lung alveoli are covered by a $0.1-0.5 \mu \mathrm{m}$ thick epithelium lining fluid (ELF) that has a large surface area $\sim 885,000 \mathrm{~cm}^{2}$ (vs. the $\sim 4,500 \mathrm{~cm}^{2}$ of the airway). ${ }^{1)} \mathrm{ELF}$ contains surfactant proteins $B$ and $C(\sim 10 \mathrm{wt} \%$ of total ELF surfactant material), ${ }^{1-6)}$ in addition to water-soluble antioxidants such as glutathione ([GSH] $\sim 100-500 \mu \mathrm{M}$ ), ascorbic acid ([Asc] $\sim 100 \mu \mathrm{M}){ }^{1,7)}$ uric acid, and liposoluble $\alpha$-tocopherol. ${ }^{7-11)}$ SP-B functions reduce the energy required to expand lungs during aspiration and prevent their collapse upon exhalation. ${ }^{12)}$ A recent simulation study revealed that SP-B induces the formation of bilayer reservoirs by monolayer folding, helps attaching the disconnected bilayer aggregates to a monolayer at the air-water interface, and facilitates lipid transfer between these structures. ${ }^{13)}$ SP-B deficiency is known to cause severe lung dysfunction and inflammation. ${ }^{14)}$ Human infants genetically lacking SP-B cannot survive. ${ }^{15)}$ It is apparent that the oxidative degradation of SP-B's surface activity should induce acute syndromes. $^{2,16-19)}$

Recent studies suggested that the inhalation of particulate matter (PM) produces $\cdot \mathrm{OH}$ in ELF. ${ }^{20-22)}$ In vivo studies have shown that $\mathrm{OH}$ produced in ELF exposed to $\mathrm{O}_{3}(\mathrm{~g})$ enhances bronchoalveolar permeability. ${ }^{23)}$ Given the abundance of antioxidants in ELF (see above), SP-B oxidative damage can be triggered only by $\cdot \mathrm{OH}$ produced or deposited close to SP-B. ${ }^{24)}$ Because inhaled gas-phase oxidants are very reactive and the SP-B surfactant is present at the ELF surface, the relevant reactive events are expected to take place at the air-water interface rather than in the bulk liquid. A previous study found that the heterogeneous reaction of $\mathrm{O}_{3}(\mathrm{~g})$ with $\mathrm{SP}-\mathrm{B}_{1-25}$ (a model 25-residue polypeptide of human SP-B ${ }^{25)}$ in water-methanol droplets yields several products that incorporate $\mathrm{O}$-atoms in a few seconds. ${ }^{3)}$ The products from the droplets exposed to $\mathrm{O}_{3}(\mathrm{~g})$ or the solution treated $\mathrm{O}_{3}$-bubbling were found to be quite different, ${ }^{3)}$ implying that the mechanism at the gas-liquid interface is different from that in bulk solution. ${ }^{7)}$ The authors also generated reactive intermediates in bulk water with Fenton's reagent $\left(\mathrm{Fe}^{2+}+\mathrm{H}_{2} \mathrm{O}_{2}\right)$ to test whether the chemistry actually involved $\cdot \mathrm{OH}$ radicals. However, we recently found that the Fenton reaction at the air-water interface produces oxo-ferryl species $\left(\mathrm{Fe}^{\mathrm{IV}}=\mathrm{O}\right)$ in high yields, which behave as $\mathrm{O}$-atom donors rather than as $\mathrm{H}$-abstracting species. ${ }^{26-30}$ ) In fact, a recent study suggested that Fenton's reaction produces $<10 \% \cdot \mathrm{OH}$ in bulk water at physiological $\mathrm{pH} 6-7{ }^{28)}$ Since the production of $\mathrm{Fe}^{\mathrm{IV}}=\mathrm{O}$ is significantly enhanced in Fenton's reaction at the air-water interface, ${ }^{26)}$ establishing the mechanism of the oxidation of SP- $\mathrm{B}_{1-25}$ initiated by $\cdot \mathrm{OH}$ at the air-water interface requires experiments involving a

*Correspondence to: Shinichi Enami, National Institute for Environmental Studies, 16-2 Onogawa, Tsukuba, Ibaraki 305-8506, Japan, e-mail: enami.shinichi@nies.go.jp 
direct, bona fide source of $\cdot \mathrm{OH}$ in situ.

In this paper we report a mass-spectrometric study specifically designed to address these issues, in which aqueous $\mathrm{SP}_{1-25}$ (a 25-residue polypeptide $\mathrm{NH}_{2}$ ${ }^{1}$ FPIPLPYCWLCRALIKRIQAMIPK $\left.{ }^{25} \mathrm{G}-\mathrm{COOH}\right)$ reacts with gas-phase $\cdot \mathrm{OH}$ at the air-water interface. $\mathrm{SP}_{-1-25}$ has been used as a representative model peptide that mimics SP-B functions, because of the similarity of their chemical and physical properties.,6) Our experiments were conducted in a novel setup in which aqueous $\mathrm{SP}_{-} \mathrm{B}_{1-25}$ microjets were intersected with gas-phase $\cdot \mathrm{OH}$ streams generated in close proximity to the surface via pulsed laser photolysis of $\mathrm{O}_{3}(\mathrm{~g}) / \mathrm{H}_{2} \mathrm{O}(\mathrm{g}) / \mathrm{O}_{2}(\mathrm{~g}) / \mathrm{N}_{2}(\mathrm{~g})$ mixtures, ${ }^{31-36)}$ while continuously monitoring the composition of the interfacial layers of the microjets via pneumatic ionization mass spectrometry. ${ }^{37-39)}$

\section{EXPERIMENTAL SECTION}

The present experimental setup is essentially the same as the one reported elsewhere. ${ }^{31)}$ The charged product species generated on the surface of $\mathrm{SP}_{-\mathrm{B}_{1-25}(\mathrm{aq}) \mathrm{mi}-}$ crojets during $\tau \sim 10 \mu$ s contact times ( $\tau$ is the lifetime of the microjets before being pneumatically nebulized) with $\mathrm{O}_{3}(\mathrm{~g})$ or $\cdot \mathrm{OH}(\mathrm{g})$ streams are monitored in-situ by online mass spectrometry (Fig. S1, Agilent 6130 Quadrupole LC/MS Electrospray System). ${ }^{31)} \mathrm{O}\left({ }^{1} \mathrm{D}\right)$ generated by $266 \mathrm{~nm}$ photons reacts with excess $\mathrm{H}_{2} \mathrm{O}(\mathrm{g})$ $\left(\left[\mathrm{H}_{2} \mathrm{O}(\mathrm{g})\right] \sim 7.6 \times 10^{17}\right.$ molecule $\left.\mathrm{cm}^{-3}\right)$ to form $\cdot \mathrm{OH}$ radicals within $\sim 6 \mathrm{~ns}$ (from $k_{1}\left(\mathrm{O}\left({ }^{1} \mathrm{D}\right)+\mathrm{H}_{2} \mathrm{O}\right)=2.2 \times 10^{-10} \mathrm{~cm}^{3} \mathrm{~mol}-$ ecule $^{-1} \mathrm{~s}^{-1}$ ) (see $[\cdot \mathrm{OH}(\mathrm{g})]$ estimates in SI). These conditions ensure that the detected species correspond to the truly initial stages of reaction. ${ }^{34-36)}$ The all- ${ }^{12} \mathrm{C}$ isotopomer of SP$\mathrm{B}_{1-25} \equiv \mathrm{Phe}_{1}-\mathrm{Pro}_{2}-\mathrm{Ile}_{3}-\mathrm{Pro}_{4}-\mathrm{Leu}_{5}-\mathrm{Pro}_{6}-\mathrm{Tyr}_{7}-\mathrm{Cys}_{8}-\mathrm{Trp}_{9}-$ $\mathrm{Leu}_{10}-\mathrm{Cys}_{11}-\mathrm{Arg}_{12}-\mathrm{Ala}_{13}-\mathrm{Leu}_{14}-\mathrm{Ile}_{15}-\mathrm{Lys}_{16}-\mathrm{Arg}_{17}-\mathrm{Ile}_{18}-$ $\mathrm{Gln}_{19}-\mathrm{Ala}_{20}-\mathrm{Met}_{21}-\mathrm{Ile}_{22}-\mathrm{Pro}_{23}-\mathrm{Lys}_{24}-\mathrm{Gly}_{25}$, has a molecular mass of $2928 \mathrm{Da}$. Samples are injected at $100 \mu \mathrm{L} \mathrm{min}^{-1}$ into the spraying chamber of the mass spectrometer through a grounded stainless steel needle $(100 \mu \mathrm{m}$ bore) coaxial with a sheath issuing nebulizer $\mathrm{N}_{2}(\mathrm{~g})$ at a high velocity $\left(v_{\mathrm{g}} \approx 160 \mathrm{~m} / \mathrm{s}\right) .{ }^{38)}$ The surface specificity of our experiments has been demonstrated previously. ${ }^{26,37,38,40,41)}$ It should be emphasized that the products we observe are formed when gaseous reactants collide with the intact aqueous jets as they emerge from the nozzle, i.e., before jets are broken up into sub-micron charged droplets by the nebulizer gas. ${ }^{26)}$ Since $266 \mathrm{~nm}$ pulses flash every $100 \mathrm{~ms}$, and the microjets breaks up within $\sim 10 \mu$ s after being ejected from the nozzle, it is safe to assume that the observed phenomena always take place on the surface of fresh solutions. ${ }^{31)}$

We verified that in the absence of $\mathrm{O}_{3}(\mathrm{~g})$ neither reactant signals are affected nor new product signals appear upon $266 \mathrm{~nm}$ pulsed irradiation, thereby excluding the photolysis SP-B ${ }_{1-25}(\mathrm{aq})$ as the source of detected products (see Fig. S2). In our experiments, $\cdot \mathrm{OH}(\mathrm{g})$ will stick to the surface of water in nearly every collision, ${ }^{31,33-35,42-46)}$ and react with $\mathrm{SP}^{-\mathrm{B}_{1-25}}$ (R1), or dimerize into $\mathrm{H}_{2} \mathrm{O}_{2}$ (R2) at the air-water interface.

$$
\begin{gathered}
\mathrm{SP}-\mathrm{B}_{1-25}+\cdot \mathrm{OH} \rightarrow \text { products } \\
\cdot \mathrm{OH}+\cdot \mathrm{OH} \rightarrow \mathrm{H}_{2} \mathrm{O}_{2}
\end{gathered}
$$

The preference of $\cdot \mathrm{OH}$ for interfacial layers relative to the bulk liquid is supported both by theoretical and experimen- tal studies. ${ }^{31,32,34,43-46)}$ This effect should enhance the probability of $\cdot \mathrm{OH}$ reactions with hydrophobic residues at the air-water interface before it diffuses into bulk phase.

\section{RESULTS AND DISCUSSION}

Figure 1A shows a positive ion mass spectrum of $43 \mu \mathrm{M}$ SP- $\mathrm{B}_{1-25}(\mathrm{aq})$ microjets exposed to $\mathrm{O}_{2}(\mathrm{~g}) / \mathrm{H}_{2} \mathrm{O}(\mathrm{g}) / \mathrm{N}_{2}(\mathrm{~g})$, and to $\mathrm{O}_{3}(\mathrm{~g}) / \mathrm{O}_{2}(\mathrm{~g}) / \mathrm{H}_{2} \mathrm{O}(\mathrm{g}) / \mathrm{N}_{2}(\mathrm{~g})$ with the $266 \mathrm{~nm}$ laser on and off. The three major peaks at $m / z=586.7,733.0$ and 977.0 correspond to multiply protonated $\left[\mathrm{SP}-\mathrm{B}_{1-25}+m\right.$ $\mathrm{H}]^{m+}$ for $m=5,4$ and 3 , respectively. It is apparent that $\left[\mathrm{SP}_{-1-25}+4 \quad \mathrm{H}\right]^{4+} \quad\left[\mathrm{NH}_{2}-\right.$ FPIPLPYCWLCR $\left(\mathrm{H}^{+}\right) \operatorname{ALIK}\left(\mathrm{H}^{+}\right)-$ $\left.\mathrm{R}\left(\mathrm{H}^{+}\right) \mathrm{IQAMIPK}\left(\mathrm{H}^{+}\right) \mathrm{G}-\mathrm{COOH}\right)^{4+}$ is the most abundant species under present conditions. We found that the relative abundances of the most protonated species increase at lower $\mathrm{SP}_{-\mathrm{B}_{1-25}}(\mathrm{aq})$ concentrations (Fig. S3), a phenomenon that we tentatively ascribe to decreased repulsion among sparser polycationic chains in the air-water interfacial layers sampled by our technique. Hereafter, our analysis will largely focus on the evolution of the $m / z^{+}=733.0\left[\mathrm{SP}_{-1-25}+4\right.$ $\mathrm{H}]^{4+}$ species upon variations of experimental conditions.

All $\left[\mathrm{SP}-\mathrm{B}_{1-25}+m \mathrm{H}\right]^{m+}$ signals decrease and new products appear (Figs. $1 \mathrm{~A}$ and $1 \mathrm{~B}$, blue trace) in the presence of $\mathrm{O}_{3}(\mathrm{~g})$ without $266 \mathrm{~nm}$. Thus, $\mathrm{SP}-\mathrm{B}_{1-25}$ is found to be reactive toward $\mathrm{O}_{3}$, in accordance with literature reports. ${ }^{3,6,47)}$

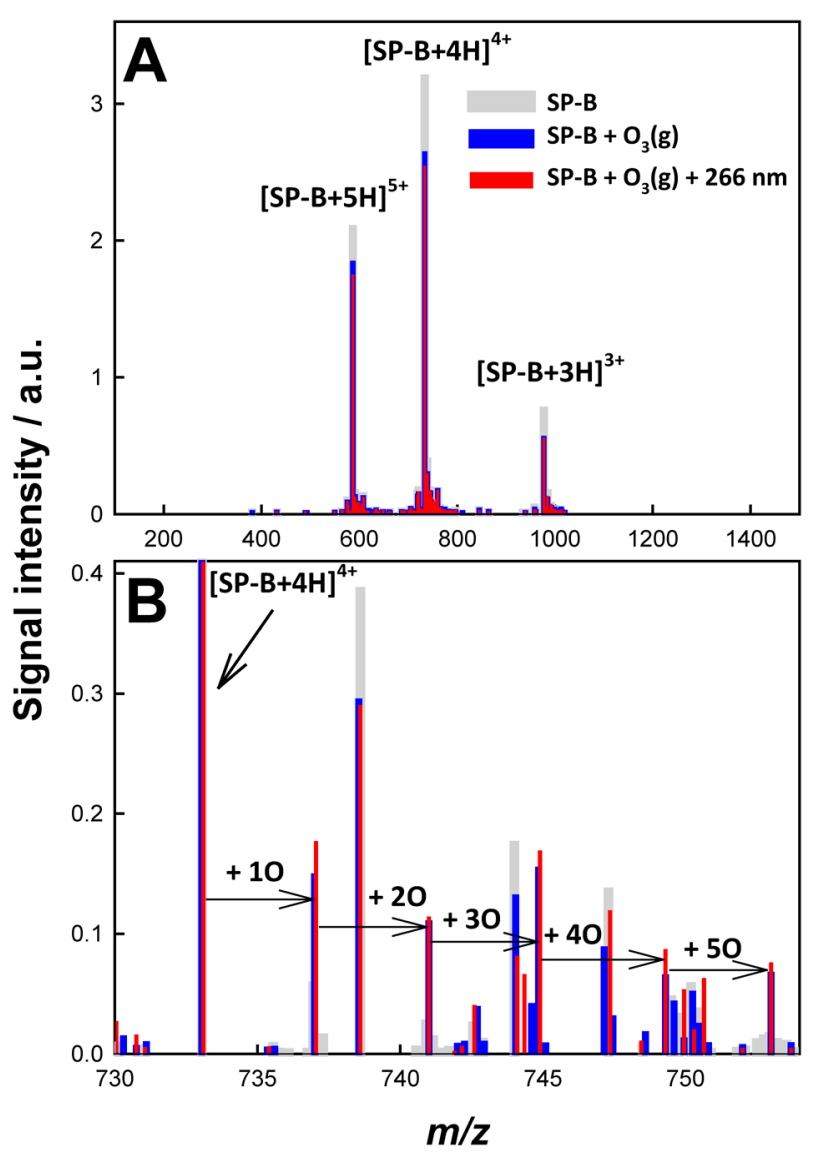

Fig. 1. A) Positive ion mass spectra of aqueous $43 \mu \mathrm{M}$ SP- $B_{1-25} \mathrm{mi}-$ crojets in $\mathrm{O}_{2}(\mathrm{~g}) / \mathrm{H}_{2} \mathrm{O}(\mathrm{g}) / \mathrm{N}_{2}(\mathrm{~g})$ mixtures (gray), or exposed to $\sim 500 \mathrm{ppmv}_{3}(\mathrm{~g})$ in $\mathrm{O}_{2}(\mathrm{~g}) / \mathrm{H}_{2} \mathrm{O}(\mathrm{g}) / \mathrm{N}_{2}(\mathrm{~g})$ mixtures in the absence (blue)/in the presence (red) of $40 \mathrm{~mJ} 266 \mathrm{~nm}$ pulses. $1 \mathrm{ppmv}=2.46 \times 10^{13}$ molecules $\mathrm{cm}^{-3}$. B) Spectra of $\left[\mathrm{SP}-\mathrm{B}_{1-25}+4\right.$ $\left.\mathrm{H}^{+}\right]^{4+}$ and its oxidation products in the $730-760 \mathrm{Da}$ range. 
In Fig. $1 \mathrm{~B}$, the $m / z^{+}=737=[2928+4(+4 \mathrm{H})+16(+\mathrm{O})] / 4$ signal is assigned to $\left[\mathrm{SP}-\mathrm{B}_{1-25}+4 \mathrm{H}+\mathrm{O}\right]^{4+}$. The $m / z^{+}=741=[2928+4$ $(+4 \mathrm{H})+32(+2 \mathrm{O})] / 4$ signal is $\left[\mathrm{SP}-\mathrm{B}_{1-25}+4 \mathrm{H}+2 \mathrm{O}\right]^{4+}$, i.e., $m / z^{+}=733+4 n$ is $\left[\mathrm{SP}_{-1-25}+4 \mathrm{H}+n \mathrm{O}\right]^{4+}(n=1-5)$. We did not detect $n \geq 6$ products in our experiments. Importantly, the application of $266 \mathrm{~nm}$ laser pulses enhances all product signals (Fig. 1B, red trace), thereby suggesting that the detectable products of $\mathrm{SP}-\mathrm{B}_{1-25}$ oxidation by $\mathrm{O}_{3}$ and $\cdot \mathrm{OH}$ might be identical. This finding is in accordance with previous reports on the ozonation of amino acids, ${ }^{48)}$ and the $\cdot \mathrm{OH}-$ initiated oxidation of proteins. ${ }^{49}$

Figure 2 shows $\left[\mathrm{SP}^{\mathrm{B}} \mathrm{B}_{1-25}+4 \mathrm{H}+n \quad \mathrm{O}\right]^{4+}$ mass spectral signal intensities from $\mathrm{SP}_{-1-25}(\mathrm{aq})$ microjets exposed to $\mathrm{O}_{3}(\mathrm{~g}) / \mathrm{O}_{2}(\mathrm{~g}) / \mathrm{H}_{2} \mathrm{O}(\mathrm{g}) / \mathrm{N}_{2}(\mathrm{~g})$ mixtures under on and off $266 \mathrm{~nm}$ pulses as functions of $\left[\mathrm{O}_{3}(\mathrm{~g})\right]$. It is apparent that
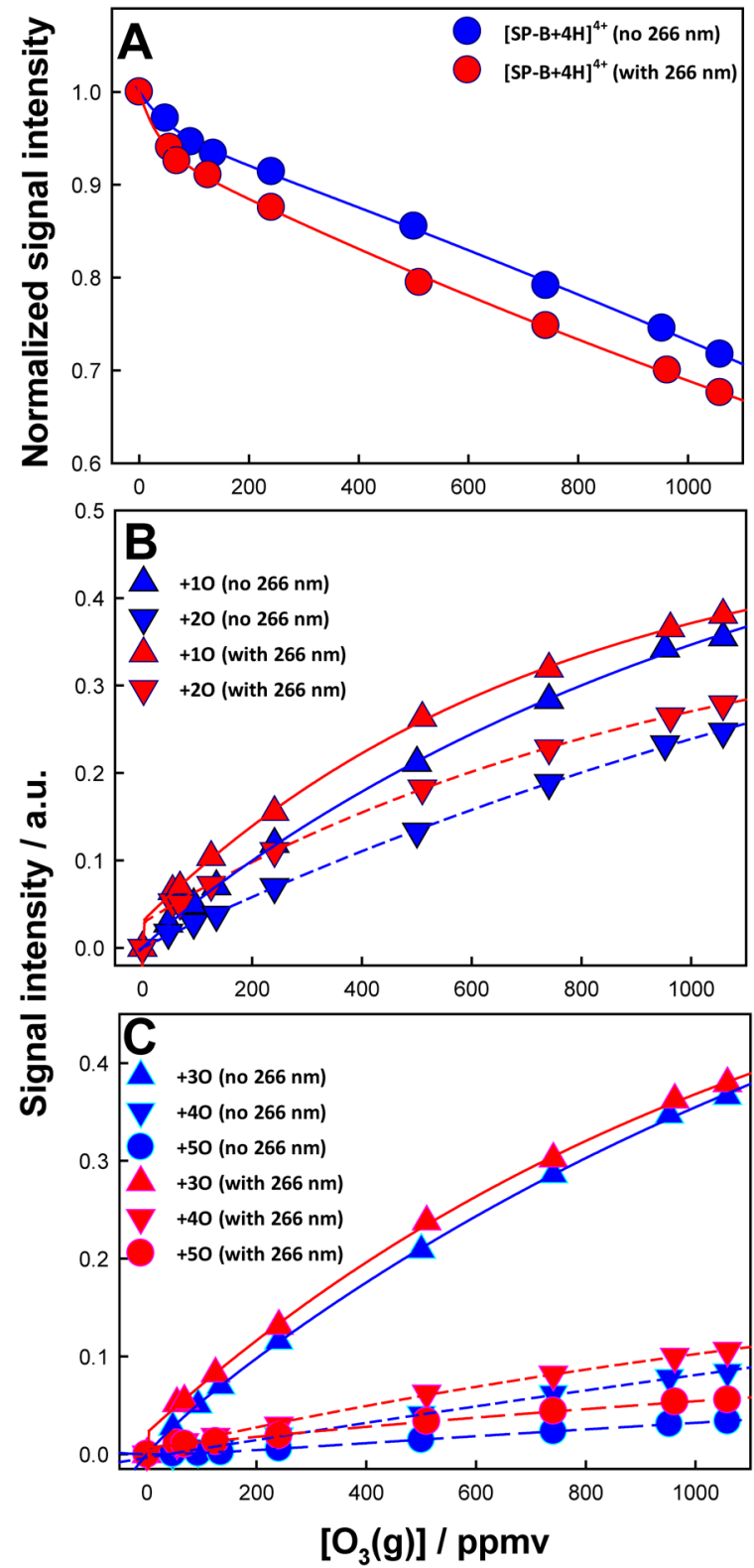

Fig. 2. Reactant (A) and products (B, C) mass spectral signal intensities from aqueous $43 \mu \mathrm{M}$ SP- $B_{1-25}$ microjets exposed to $\mathrm{O}_{3}(\mathrm{~g}) / \mathrm{O}_{2}(\mathrm{~g}) / \mathrm{H}_{2} \mathrm{O}(\mathrm{g}) / \mathrm{N}_{2}(\mathrm{~g})$ mixtures in the absence (blue) or presence (red) of $266 \mathrm{~nm}$ laser beams $\left(40 \mathrm{mJpulse}^{-1}\right)$ as a function of the $\mathrm{O}_{3}(\mathrm{~g})$ mixing ratio; $1 \mathrm{ppmv}=2.46 \times 10^{13} \mathrm{~mol}$ ecules $\mathrm{cm}^{-3}$. the depletion of $\mathrm{SP}-\mathrm{B}_{1-25}$ is more extensive and $\left[\mathrm{SP}-\mathrm{B}_{1-25}+4\right.$ $\mathrm{H}+n \mathrm{O}]^{4+}(n=1-5)$ production is enhanced upon irradiation. Note the simultaneous appearance of all $n=1-5\left[\mathrm{SP}_{-1-25}+4\right.$ $\mathrm{H}+n \mathrm{O}]^{4+}$ products (see below). Figure $\mathrm{S} 4$ compares the bi-exponential depletion of $\left[\mathrm{SP}_{-1-25}+3 \mathrm{H}\right]^{3+},\left[\mathrm{SP}_{1-25}+4\right.$ $\mathrm{H}]^{4+}$ and $\left[\mathrm{SP}_{-} \mathrm{B}_{1-25}+5 \mathrm{H}\right]^{5+}$ signal intensities under the same conditions of Fig. 2. The fact that the extent of $\left[\mathrm{SP}-\mathrm{B}_{1-25}+3\right.$ $\mathrm{H}]^{3+}$ depletion is significantly larger than for the other protonated species suggests structural changes that depend on $m^{50-52)}$ Species of smaller $m$ values behave as if they increase the exposure of the more hydrophobic (surfaceactive) amino acid residues to $\mathrm{O}_{3}$ and $\cdot \mathrm{OH}$. This is consistent with experiments showing that more hydrophobic long-chain species react more extensively with $\cdot \mathrm{OH}(\mathrm{g})$ than the less hydrophobic shorter-chain ones. ${ }^{31,32,34,35)}$ This is also consistent with a recent report showing that antioxidant activity of free amino acids in Fenton's reaction increases with

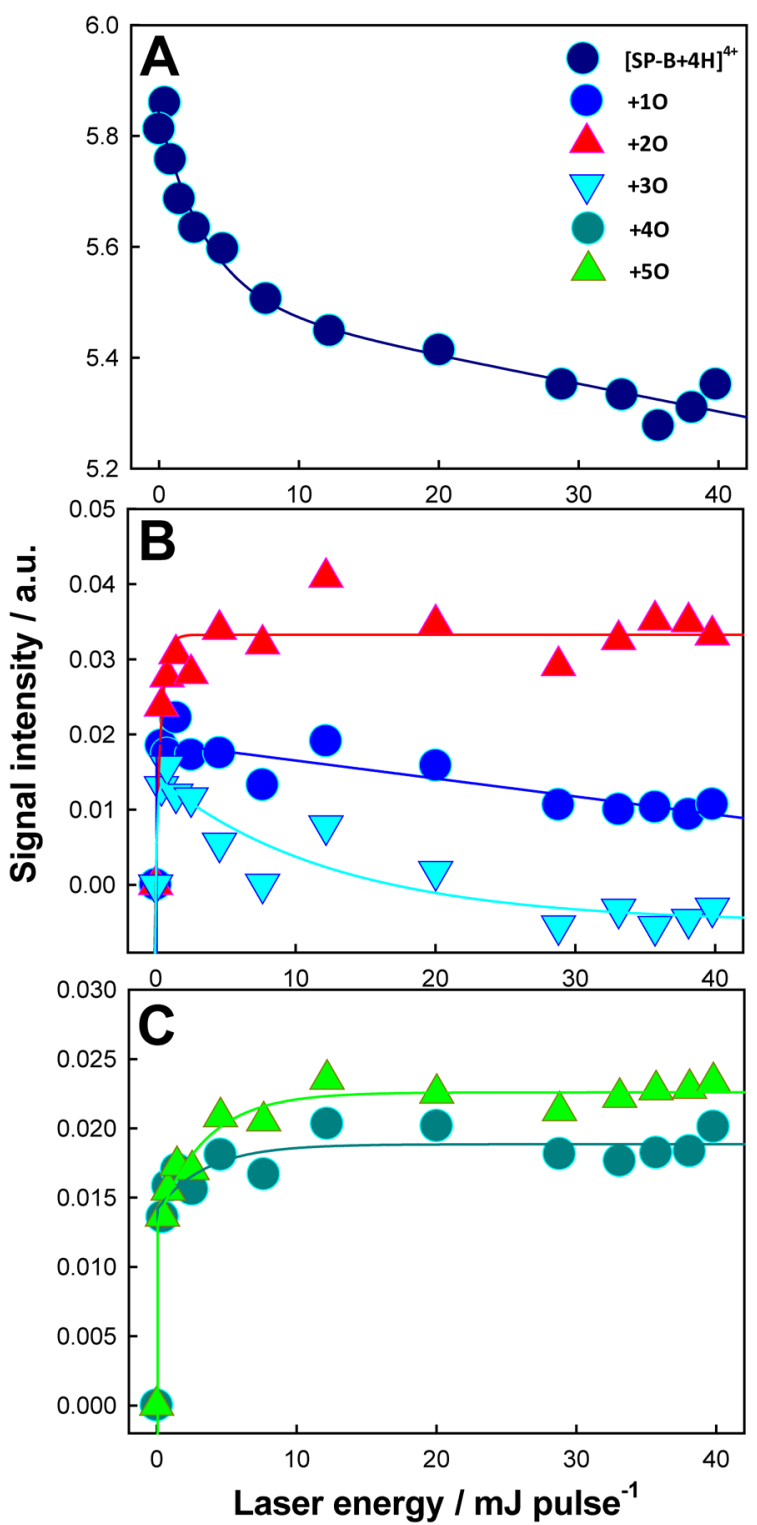

Fig. 3. Reactant (A) and products (B, C) mass spectral signal intensities from aqueous $43 \mu \mathrm{M}$ SP- $B_{1-25}$ microjets exposed to $\mathrm{O}_{3}(\mathrm{~g}) / \mathrm{O}_{2}(\mathrm{~g}) / \mathrm{H}_{2} \mathrm{O}(\mathrm{g}) / \mathrm{N}_{2}(\mathrm{~g})$ mixtures at $\left[\mathrm{O}_{3}(\mathrm{~g})\right] \sim 600 \mathrm{ppmv}$, irradiated with $266 \mathrm{~nm}$ laser beams as functions of laser energy (in mJpulse $\mathrm{m}^{-1}$ ). Background (before pulsing at $266 \mathrm{~nm}$ ) products signals were subtracted. 
hydrophobicity. ${ }^{53)}$

Figure 3 shows reactant decay and product enhancements upon irradiation in similar experiments as functions of $266 \mathrm{~nm}$ pulse energy. In Fig. 3, laser energies ( $x$-axis) at 1 , $5,10,20,30$, and $40 \mathrm{~mJ}$ pulse $^{-1}$ correspond to $[\cdot \mathrm{OH}(\mathrm{g})]_{0} \approx 2$, $9,18,33,46$, and $57 \mathrm{ppmv}$, respectively. The actual $[\cdot \mathrm{OH}]$ colliding to the microjets are expected to be smaller than these estimated values. ${ }^{34,35)}$ It is apparent that the full extent of irradiation effects is already reached at the lowest pulse energies. Further increases in pulse energy only achieve the partial degradation of the $n=1$ and $3\left[\mathrm{SP}_{-} \mathrm{B}_{1-25}+4 \mathrm{H}+n\right.$ $\mathrm{O}^{4+}$ products. $\left[\mathrm{SP}_{-} \mathrm{B}_{1-25}+4 \mathrm{H}+3 \mathrm{O}\right]^{4+}$ in particular disappears above $\sim 20 \mathrm{~mJ}$ pulse, possibly via photo-degradation or secondary reactions. The effect of laser energy on product formation (Fig. 3) is markedly different from that observed upon variations of $\left[\mathrm{O}_{3}(\mathrm{~g})\right]$ (Fig. 2): SP- $\mathrm{B}_{1-25}$ decays bi-exponentially as a function of laser energy, while some products reach steady state at the lowest fluences, such as $\left[\mathrm{SP}_{-25} \mathrm{~B}_{1-25}+4\right.$ $\mathrm{H}+2 \mathrm{O}]^{4+}$, or are degraded, such as $\left[\mathrm{SP}-\mathrm{B}_{1-25}+4 \mathrm{H}+\mathrm{O}\right]^{4+}$ and $\left[\mathrm{SP}-\mathrm{B}_{1-25}+4 \mathrm{H}+3 \mathrm{O}\right]^{4+}$, at larger fluences.

Our results are consistent with the rapid incorporation of up to $5 \mathrm{O}$-atoms to $\mathrm{SP}_{-} \mathrm{B}_{1-25}$ by both $\mathrm{O}_{3}$ and $\cdot \mathrm{OH}$ at the air-water interface. Since (i) the reported rate constants for the reactions of cysteine $\left(k_{\text {Cys+ozone }}>7.0 \times 10^{6} \mathrm{M}^{-1} \mathrm{~s}^{-1}\right)$ and tryptophan $\left(k_{\text {Trp+ozone }}=7.0 \times 10^{6} \mathrm{M}^{-1} \mathrm{~s}^{-1}\right)$ with $\mathrm{O}_{3}$ in bulk water are $>10^{2}$ times larger than for the rest of the amino acids (except for methionine), ${ }^{48)}$ (ii) the corresponding reactions with $\cdot \mathrm{OH} \quad\left(k_{\mathrm{Trp}+\mathrm{OH}}=1.3 \times 10^{10} \mathrm{M}^{-1} \mathrm{~s}^{-1}\right)$, $\left(\mathrm{k}_{\mathrm{Cys}+\mathrm{OH}}=3.5 \times 10^{10} \mathrm{M}^{-1} \mathrm{~s}^{-1}\right)$ are diffusionally controlled, (iii) both cysteines Cys $s_{8}$ and $\mathrm{Cys}_{11}$, and tryptophan Trp , are embedded in the hydrophobic section of $\mathrm{SP}_{-} \mathrm{B}_{1-25}$ that resides at the topmost layers of air-water interface, ${ }^{3,54)}$ we infer that these are the three amino acid residues attacked by both $\mathrm{O}_{3}$ and $\cdot \mathrm{OH}$. More specifically, we envision that in the initial stages of the oxidation process $\mathrm{O}_{3}$ will transfer one $\mathrm{O}$-atom to the sulfhydryl R-S-H group of Cys to produce the corresponding sulfenic acid $\mathrm{R}-\mathrm{S}-\mathrm{OH},{ }^{55)}$ whereas $\mathrm{O}_{3}$ also adds to the pyrrole ring of Trp to produce the corresponding primary $\mathrm{POZ}$ and secondary $\mathrm{SOZ}$ Trp- $\mathrm{O}_{3}$ ozonides (Scheme S1). We also consider that the S-containing methionine $\mathrm{Met}_{21}$ residue, ${ }^{56}$ by being situated in the hydrophilic C-terminal side buried in water (as shown by MD simulations by Goddard and coworkers), ${ }^{3)}$ is less likely to be oxidized by both $\mathrm{O}_{3}$ and $\cdot \mathrm{OH}$ than the Cys residues closer to the air-water interface. The fact that both $\mathrm{O}_{3}$ and $\cdot \mathrm{OH}$ preferably reside at the air-water interface rather than in bulk ${ }^{44-46)}$ makes it less likely that they will diffuse towards the $\mathrm{Met}_{21}$ residue located in bulk.

We also tested whether the mechanism of Trp ozonation at the air-water interface follows the same course as in bulk water in our experimental setup by exposing free L-tryptophan (aq) to $\mathrm{O}_{3}(\mathrm{~g}) / \mathrm{O}_{2}(\mathrm{~g}) / \mathrm{H}_{2} \mathrm{O}(\mathrm{g}) / \mathrm{N}_{2}(\mathrm{~g})$ mixtures in the absence/presence of $266 \mathrm{~nm}$ pulses (Fig. S5). We found that the interfacial ozonation of anionic Ltryptophan $\left(m / z^{-}=203\right)$ produces species that incorporate one to three $\mathrm{O}$-atoms, which are detected at $\mathrm{m} / \mathrm{z}^{-}=219$ $(+1 \mathrm{O}), 235(+2 \mathrm{O})$ and $251(+3 \mathrm{O})$, along with a signal at $m / z^{-}=207$. These species match the masses of the reported products of Trp ozonation ${ }^{3,57)}$ and hydroxylation ${ }^{58,59)}$ in bulk water. See Scheme S1 for assignments. We note, however, that the formation of kynurenine (Kyn) from the oxidation of $\operatorname{Trp}_{9}$ in $\mathrm{SP}_{-1-25}$, which would have led to a peak at $m / z^{+}=734=\left[2928+48(+3 \mathrm{O})-44\left(-\mathrm{CO}_{2}\right)+4(+4 \mathrm{H})\right] / 4$, is absent from our mass spectra (Fig. 1B). Thus, from the fact that we observe the incorporation of up to $5 \mathrm{O}$-atoms into SP- $\mathrm{B}_{1-25}$, we conclude that $\operatorname{Trp}_{9}$ accepts $3 \mathrm{O}$-atoms, and $\mathrm{Cys}_{8}$ and $\mathrm{Cys}_{11}$ one $\mathrm{O}$-atom each during the ozonation and hydroxylation of $\mathrm{SP}_{-} \mathrm{B}_{1-25}$ at the air-water interface under present conditions. Note that $\mathrm{H}$-abstraction from Trp by . $\mathrm{OH}$ in the presence of $\mathrm{O}_{2}$ would have led to the formation of a peroxyl radical, $m / z^{-}=203-1(-\mathrm{H})+32\left(+\mathrm{O}_{2}\right)=234$, and possibly to an alcohol $\mathrm{m} / \mathrm{z}^{-}=234-16+1=219$, and carbonyl $m / z^{-}=234-16-1=217$, from the disproportionation of the peroxyl radical, as in the case of alkyl and aromatic carboxylic acids. ${ }^{31,32,34,35)}$ Their conspicuous absence proves that under present conditions all oxidation processes, both those initiated by ozonation and hydroxylation, are initiated by $\mathrm{O}$-atom transfers or $\mathrm{OH}$ additions to the $\mathrm{S}$-center of the Cys and the pyrrole ring of Trp, rather than by $\mathrm{H}$-atom abstraction from the myriad $\mathrm{C}-\mathrm{H}$ bonds available in $\mathrm{SP}-\mathrm{B}_{1-25}$. The exceptional reactivity of $\mathrm{S}$-atoms in biomolecules for $\cdot \mathrm{OH}$-addition is consistent with our $\mathrm{GSH}+\cdot \mathrm{OH}$ and $\mathrm{GSSG}+\cdot \mathrm{OH}$ studies at the air-water interface, ${ }^{36)}$ suggesting that interface-specific phenomena are general and stem from the peculiar nature of interfacial water as a reaction medium. ${ }^{26,60-62)}$ We also note that these highly selective oxidations imply "molecular recognition" processes, possibly mediated by water networks. ${ }^{63,64)}$ Thus, our results suggest that these hitherto unknown interface-specific radical recognition processes may play central roles in lung surface chemistry.

The occurrence of up to $5 \mathrm{O}$-atom transfers to a single SP- $B_{1-25}$ unit implies that oxidants are always in excess over reactive centers at the interface. Thus, the initial attack on any one of them is followed by additional, successive $\mathrm{O}$-atom transfers until all such centers reach their limiting degree of oxidation during contact times. However, since we have shown that GSH and free cysteine can add up to $3 \mathrm{O}$-atoms under similar conditions, ${ }^{36,55)}$ it appears that first-generation sulfenic acids $\mathrm{S}(\mathrm{O})-\mathrm{H}$ are not further oxidized in $\mathrm{SP}_{-} \mathrm{B}_{1-25}$. This is because they may rapidly form $\mathrm{S}-\mathrm{S}$ bridges or, due to conformational changes, they become buried in the hydrophilic segment of the polypeptide. ${ }^{65)}$ In this context, we note that the fate of sulfenic acid could be determined by the microenvironment. ${ }^{65,66)}$ For example, a $\mathrm{S}-\mathrm{OH}$ can persist for several hours in human serum albumin, in which 34 of 35 cysteine-resides can create disulfidebonds thereby minimizing the number of available reduced S-atoms. ${ }^{67)}$ Another study revealed that the hypervalent $\mathrm{S}$-atoms of sulfenic acids can form covalent complexes with the $\mathrm{N}$-atoms of neighboring histidine residues, a phenomenon that prevents the over-oxidation of cysteine sulfenic acid. ${ }^{68)}$ Therefore, it is conceivable that neighboring Trp ${ }_{9}$ 's indole-N-atoms may stabilize the $\mathrm{Cys}_{8}-\mathrm{OH}$ and $\mathrm{Cys}_{11}-\mathrm{OH}$ in a similar way. An additional effect is that since sulfinic $\mathrm{S}\left(\mathrm{O}_{2}\right)-\mathrm{H}\left(\mathrm{p} K_{\mathrm{a}} \approx 2\right)$ and sulfonic acids $\mathrm{S}\left(\mathrm{O}_{2}\right)-\mathrm{OH}\left(\mathrm{p} K_{\mathrm{a}}<1\right)$ are much more acidic than $\left.\mathrm{S}(\mathrm{O})-\mathrm{H}\left(\mathrm{p} K_{\mathrm{a}} \approx 7.6\right),{ }^{55}\right)$ they would deprotonate at $\mathrm{pH} \sim 6$ thereby decreasing the net charge of $\left[\mathrm{SP}-\mathrm{B}_{1-25}+m \mathrm{H}+\mathrm{O}\right]^{m+}$ from $m \rightarrow(m-1)$ and shifting the mass signals. However, the fact that we did not observe such behavior (Fig. S3) led us to exclude the oxidation of Cyssulfenic acid residues.

The mechanism of $\mathrm{SP}-\mathrm{B}_{1-25}$ oxidations shown here is generally consistent with previous studies. ${ }^{3,6,47)}$ However, 
the previous report using the Fenton reaction for oxidizing SP- $\mathrm{B}_{1-25}$ by $\cdot \mathrm{OH}$ in bulk water showed $\mathrm{O}_{n}$-products up to $n=10$, which is in contrast with our observations $(n=1-5) .{ }^{3)}$ We ascribe this to the following reasons: 1) differences between bulk vs. interfacial mechanism, 2) the very different time scales between the two systems, and 3) the Fenton reaction may largely produce oxo-ferryls rather than $\cdot \mathrm{OH}$. First, as observed in GSH/GSSH+. OH experiments, ${ }^{36)}$ the difference indeed comes from where the $\cdot \mathrm{OH}$-reaction occurs, that is, in water $v s$. at the air-water interface. We recently reported that $\cdot \mathrm{OH}$-reaction of amphiphilic species are remarkably different in bulk water $v s$. at the air-water interface. ${ }^{32,34,35)}$ Second, in the previous report the measurement was performed $>12 \mathrm{~h}$ after the Fenton reaction starts, ${ }^{3)}$ while in the present study the time scale is $<10 \mu$ s. Third, as mentioned above, the Fenton reaction may produce oxoferryl species in $>90 \%$ yields in bulk water at $\mathrm{pH} 6-7,{ }^{28)}$ and even more so at the air-water interface. ${ }^{26)}$ In the present work, $\cdot \mathrm{OH}$ is generated by well-established gas-phase photo-reactions. ${ }^{31)}$

Hydroxylation, by increasing the hydrophilicity of the $\mathrm{N}$-terminus, is generally expected to degrade the tensioactive properties of SP-B. ${ }^{6,47,69)}$ The formation of intra/intermolecular S-S bonding via sulfenic R-S-OH groups, that likely occurs in a longer time scale, could also disturb SP-B function as surfactant. ${ }^{5,6,13)}$ Since inhalation of $\mathrm{PM}$ and $\mathrm{O}_{3}$ evidently induces reactive oxygen species (ROS) in ELF of our lungs, ${ }^{20)}$ the present results are directly linked to adverse health effects of air pollutants impairing the role of SP-B as the surfactant.

\section{CONCLUSION}

We report a mass spectrometric study on how aqueous $\mathrm{SP}_{-} \mathrm{B}_{1-25}$ is oxidized by $\mathrm{O}_{3}$ and $\cdot \mathrm{OH}$ at the air-water interface. By using a novel method that combines online pneumatic ionization mass spectrometry with pulse laser flash photolysis, ${ }^{31)}$ we were able to detect the intermediates/ products generated in the initial stages of the oxidation of $\mathrm{SP}-\mathrm{B}_{1-25}$ by $\cdot \mathrm{OH}$ on water surfaces. Our results suggest that two Cys-residues and a Trp-residue in hydrophobic $\mathrm{N}$-terminal side are the major targets for both $\mathrm{O}_{3}$ and . $\mathrm{OH}$, rather than $\mathrm{H}$-atom abstraction from the multiple $\mathrm{C}-\mathrm{H} / \mathrm{N}-\mathrm{H}$ bonds available in $\mathrm{SP}-\mathrm{B}_{1-25}$. We infer that this remarkable interface-specific radical recognition process is what determines the observed chemistry. These chemical transformations increase the polarity of the SP- $\mathrm{B}_{1-25}$ hydrophobic section, promote the formation of disulfide links therein and, therefore, are deemed to impair its role as the surfactant that prevents lung collapse upon expiration.

\section{SUPPORTING INFORMATION AVAILABLE}

Additional data and experimental details. This material is available free of charge via the Internet.

\section{Acknowledgements}

S. E. is grateful to the Japan Science and Technology Agency (JST) PRESTO program and the Research Foundation for Opto-Science and Technology. S. E. is indebted to Prof. Hiroshi Masuhara for his kind advices.
A. J. C. acknowledges support from the National Science Foundation USA, grant AGS-1744353.

\section{REFERENCES}

1) C. E. Cross, A. van der Vliet, S. Louie, J. J. Thiele, B. Halliwell. Oxidative stress and antioxidants at biosurfaces: Plants, skin, and respiratory tract surfaces. Environ. Health Perspect. 106(Suppl. 5): 1241-1251, 1998.

2) B. Müller, C. Seifart, P. J. Barth. Effect of air pollutants on the pulmonary surfactant system. Eur. J. Clin. Invest. 28: 762-777, 1998.

3) H. I. Kim, H. Kim, Y. S. Shin, L. W. Beegle, S. S. Jang, E. L. Neidholdt, W. A. Goddard, J. R. Heath, I. Kanik, J. L. Beauchamp. Interfacial reactions of ozone with surfactant protein B in a model lung surfactant system. J. Am. Chem. Soc. 132: 2254-2263, 2010. doi: 10.1021/ja908477w

4) M. L. Longo, A. M. Bisagno, J. A. N. Zasadzinski, R. Bruni, A. J. Waring. A function of lung surfactant protein SP-B. Science 261: 453-456, 1993. doi: 10.1126/science. 8332910

5) J. Pérez-Gil. Structure of pulmonary surfactant membranes and films: The role of proteins and lipid-protein interactions. Biochim. Biophys. Acta 1778: 1676-1695, 2008. doi: https://doi. org/10.1016/j.bbamem.2008.05.003

6) J. M. Hemming, B. R. Hughes, A. R. Rennie, S. Tomas, R. A Campbell, A. V. Hughes, T. Arnold, S. W. Botchway, K. C. Thompson. Environmental pollutant ozone causes damage to lung surfactant protein B (SP-B). Biochemistry 54: 5185-5197, 2015. doi: 10.1021/acs.biochem.5b00308

7) S. Enami, M. R. Hoffmann, A. J. Colussi. Acidity enhances the formation of a persistent ozonide at aqueous ascorbate/ozone gas interfaces. Proc. Natl. Acad. Sci. U.S.A. 105: 7365-7369, 2008. doi: 10.1073/pnas.0710791105

8) S. Enami, A. R. Hoffmann, A. J. Colussi. Ozonolysis of uric acid at the air/water interface. J. Phys. Chem. B 112: 4153-4156, 2008.

9) S. Enami, M. R. Hoffmann, A. J. Colussi. How phenol and alphatocopherol react with ambient ozone at gas/liquid interfaces. $J$. Phys. Chem. A 113: 7002-7010, 2009. doi: 10.1021/jp901712k

10) S. Enami, M. R. Hoffmann, A. J. Colussi. Absorption of Inhaled $\mathrm{NO}_{2}$. J. Phys. Chem. B 113: 7977-7981, 2009. doi: 10.1021/ jp902667x

11) H. I. Kim, H. Kim, Y. S. Shin, L. W. Beegle, W. A. Goddard, J. R. Heath, I. Kanik, J. L. Beauchamp. Time resolved studies of interfacial reactions of ozone with pulmonary phospholipid surfactants using field induced droplet ionization mass spectrometry. $J$. Phys. Chem. B 114: 9496-9503, 2010. doi: 10.1021/jp102332g

12) S. Hawgood, K. Shiffer. Structures and properties of the surfac tant-associated proteins. Annu. Rev. Physiol. 53: 375-394, 1991 doi: 10.1146/annurev.ph.53.030191.002111

13) S. Baoukina, D. P. Tieleman. Lung surfactant protein SP-B promotes formation of bilayer reservoirs from monolayer and lipid transfer between the interface and subphase. Biophys. J. 100: 1678-1687, 2011. doi: 10.1016/j.bpj.2011.02.019

14) M. Ikegami, J. A. Whitsett, P. C. Martis, T. E. Weaver. Reversibility of lung inflammation caused by SP-B deficiency. Am. J. Physiol. Lung Cell. Mol. Physiol. 289: L962-L970, 2005. doi: 10.1152/ajplung.00214.2005

15) L. M. Nogee, G. Garnier, H. C. Dietz, L. Singer, A. M. Murphy, D. E. deMello, H. R. Colten. A mutation in the surfactant protein $\mathrm{B}$ gene responsible for fatal neonatal respiratory disease in multiple kindreds. J. Clin. Invest. 93: 1860-1863, 1994. doi: 10.1172/ JCI117173

16) R. Banerjee. Surface chemistry of the lung surfactant system: Techniques for in vitro evaluation. Curr. Sci. 82: 420-428, 2002.

17) J. G. Fernsler, J. A. Zasadzinski. Competitive adsorption: A physical model for lung surfactant inactivation. Langmuir 25: 8131-8143, 2009. doi: 10.1021/la8039434 
18) F. J. Kelly, S. Birch. Pulmonary protein-synthesis response to ozone. Hum. Exp. Toxicol. 13: 407-410, 1994.

19) M. C. Williams, S. Hawgood, R. L. Hamilton. Changes in lipid structure produced by surfactant proteins SP-A, SP-B, and SP-C. Am. J. Respir. Cell Mol. Biol. 5: 41-50, 1991.

20) M. Shiraiwa, K. Ueda, A. Pozzer, G. Lammel, C. J. Kampf, A. Fushimi, S. Enami, A. M. Arangio, J. Fröhlich-Nowoisky, Y. Fujitani, A. Furuyama, P. S. J. Lakey, J. Lelieveld, K. Lucas, Y. Morino, U. Pöschl, S. Takahama, A. Takami, H. Tong, B. Weber, A. Yoshino, K. Sato. Aerosol health effects from molecular to global scales. Environ. Sci. Technol. 51: 13545-13567, 2017. doi: 10.1021/acs.est.7b04417

21) H. Tong, A. M. Arangio, P. S. J. Lakey, T. Berkemeier, F. Liu, C. J. Kampf, W. H. Brune, U. Pöschl, M. Shiraiwa. Hydroxyl radicals from secondary organic aerosol decomposition in water. Atmos. Chem. Phys. 16: 1761-1771, 2016. doi: 10.5194/acp-16-1761-2016

22) E. Vidrio, C. H. Phuah, A. M. Dillner, C. Anastasio. Generation of hydroxyl radicals from ambient fine particles in a surrogate lung fluid solution. Environ. Sci. Technol. 43: 922-927, 2009. doi: $10.1021 / \mathrm{es} 801653 \mathrm{u}$

23) D. K. Bhalla. Alteration of ozone-induced airway permeability by oxygen metabolites and antioxidants. Toxicol. Lett. 73: 91-101, 1994. doi: 10.1016/0378-4274(94)90099-X

24) M. B. Goshe, Y. H. Chen, V. E. Anderson. Identification of the sites of hydroxyl radical reaction with peptides by hydrogen/deuterium exchange: Prevalence of reactions with the side chains. Biochemistry 39: 1761-1770, 2000. doi: 10.1021/bi991569j

25) M. T. Dohm, S. L. Seurynck-Servoss, J. Seo, R. N. Zuckermann, A. E. Barron. Close mimicry of lung surfactant protein B by "clicked" dimers of helical, cationic peptoids. Biopolymers 92: 538-553, 2009. doi: 10.1002/bip.21309

26) S. Enami, Y. Sakamoto, A. J. Colussi. Fenton chemistry at aqueous interfaces. Proc. Natl. Acad. Sci. U.S.A. 111: 623-628, 2014. doi: $10.1073 /$ pnas.1314885111

27) N. Yamamoto, N. Koga, M. Nagaoka. Ferryl-oxo species produced from Fenton's reagent via a two-step pathway: Minimum free-energy path analysis. J. Phys. Chem. B 116: 14178-14182, 2012. doi: 10.1021/jp310008z

28) H. Bataineh, O. Pestovsky, A. Bakac. pH-induced mechanistic changeover from hydroxyl radicals to iron(IV) in the Fenton reaction. Chem. Sci. (Camb.) 3: 1594-1599, 2012. doi: 10.1039/ c2sc20099f

29) J. T. Groves. High-valent iron in chemical and biological oxidations. J. Inorg. Biochem. 100: 434-447, 2006. doi: 10.1016/j.jinorgbio.2006.01.012

30) T. Tsuneda, T. Taketsugu. Theoretical investigations on hydrogen peroxide decomposition in aquo. Phys. Chem. Chem. Phys. 20: 24992-24999, 2018. doi: 10.1039/C8CP04299C

31) S. Enami, M. R. Hoffmann, A. J. Colussi. In situ mass spectrometric detection of interfacial intermediates in the oxidation of $\mathrm{RCOOH}(\mathrm{aq})$ by gas-phase OH-radicals. J. Phys. Chem. A 118: 4130-4137, 2014

32) S. Enami, M. R. Hoffmann, A. J. Colussi. Stepwise oxidation of aqueous dicarboxylic acids by gas-phase $\mathrm{OH}$ radicals. J. Phys. Chem. Lett. 6: 527-534, 2015. doi: 10.1021/jz502432j

33) S. Enami, Y. Sakamoto, K. Hara, K. Osada, M. R. Hoffmann, A. J. Colussi. "Sizing" heterogeneous chemistry in the conversion of gaseous dimethyl sulfide to atmospheric particles. Environ. Sci. Technol. 50: 1834-1843, 2016. doi: 10.1021/acs.est.5b05337

34) S. Enami, Y. Sakamoto. OH-radical oxidation of surface-active cis-pinonic acid at the air-water interface. J. Phys. Chem. A 120: 3578-3587, 2016. doi: 10.1021/acs.jpca.6b01261

35) S. Enami, M. R. Hoffmann, A. J. Colussi. Extensive H-atom abstraction from benzoate by $\mathrm{OH}$-radicals at the air-water interface. Phys. Chem. Chem. Phys. 18: 31505-31512, 2016. doi: 10.1039/C6CP06652F

36) S. Enami, M. R. Hoffmann, A. J. Colussi. OH-radical specific addition to glutathione S-atom at the air-water interface: Relevance to the redox balance of the lung epithelial lining fluid. J. Phys. Chem. Lett. 6: 3935-3943, 2015. doi: 10.1021/acs.jpclett.5b01819

37) S. Enami, T. Fujii, Y. Sakamoto, T. Hama, Y. Kajii. Carboxylate ion availability at the air-water interface. J. Phys. Chem. A 120: 9224-9234, 2016. doi: 10.1021/acs.jpca.6b08868

38) S. Enami, A. J. Colussi. Long-range specific ion-ion interactions in hydrogen-bonded liquid films. J. Chem. Phys. 138: 184706, 2013.

39) S. Enami, A. J. Colussi. Long-range Hofmeister effects of anionic and cationic amphiphiles. J. Phys. Chem. B 117: 6276-6281, 2013. doi: $10.1021 /$ jp $401285 f$

40) S. Enami, M. R. Hoffmann, A. J. Colussi. Proton availability at the air/water interface. J. Phys. Chem. Lett. 1: 1599-1604, 2010. doi: $10.1021 /$ jz100322w

41) H. Mishra, S. Enami, R. J. Nielsen, L. A. Stewart, M. R. Hoffmann, W. A. Goddard III, A. J. Colussi. Bronsted basicity of the air-water interface. Proc. Natl. Acad. Sci. U.S.A. 109: 1867918683, 2012. doi: 10.1073/pnas.1209307109

42) P. A. J. Bagot, C. Waring, M. L. Costen, K. G. McKendrick. Dynamics of inelastic scattering of $\mathrm{OH}$ radicals from reactive and inert liquid surfaces. J. Phys. Chem. C 112: 10868-10877, 2008. doi: 10.1021/jp8024683

43) I. J. George, J. P. D. Abbatt. Heterogeneous oxidation of atmospheric aerosol particles by gas-phase radicals. Nat. Chem. 2: 713-722, 2010. doi: 10.1038/nchem.806

44) M. Roeselová, J. Vieceli, L. X. Dang, B. C. Garrett, D. J. Tobias. Hydroxyl radical at the air-water interface. J. Am. Chem. Soc. 126: 16308-16309, 2004. doi: 10.1021/ja045552m

45) J. Vieceli, M. Roeselova, N. Potter, L. X. Dang, B. C. Garrett, D. J. Tobias. Molecular dynamics simulations of atmospheric oxidants at the air-water interface: Solvation and accommodation of $\mathrm{OH}$ and $\mathrm{O}_{3}$. J. Phys. Chem. B 109: 15876-15892, 2005.

46) M. Roeselová, P. Jungwirth, D. J. Tobias, R. B. Gerber. Impact, trapping, and accommodation of hydroxyl radical and ozone at aqueous salt aerosol surfaces. A molecular dynamics study. $J$. Phys. Chem. B 107: 12690-12699, 2003. doi: 10.1021/jp030592i

47) D. Manzanares, K. Rodriguez-Capote, S. Liu, T. Haines, Y. Ramos, L. Zhao, A. Doherty-Kirby, G. Lajoie, F. Possmayer. Modification of tryptophan and methionine residues is implicated in the oxidative inactivation of surfactant protein $\mathrm{B}$. Biochemistry 46: 5604-5615, 2007. doi: 10.1021/bi062304p

48) V. K. Sharma, N. J. D. Graham. Oxidation of amino acids, peptides and proteins by ozone: A review. Ozone Sci. Eng. 32: 81-90, 2010. doi: 10.1080/01919510903510507

49) G. H. Xu, M. R. Chance. Hydroxyl radical-mediated modification of proteins as probes for structural proteomics. Chem. Rev. 107: 3514-3543, 2007. doi: 10.1021/cr0682047

50) C. A. Cassou, H. J. Sterling, A. C. Susa, E. R. Williams. Electrothermal supercharging in mass spectrometry and tandem mass spectrometry of native proteins. Anal. Chem. 85: 138-146, 2013. doi: 10.1021/ac302256d

51) C. A. Cassou, E. R. Williams. Anions in electrothermal supercharging of proteins with electrospray ionization follow a reverse Hofmeister series. Anal. Chem. 86: 1640-1647, 2014. doi: 10.1021/ ac403398j

52) A. C. Susa, D. N. Mortensen, E. R. Williams. Effects of cations on protein and peptide charging in electrospray ionization from aqueous solutions. J. Am. Soc. Mass Spectrom. 25: 918-927, 2014 doi: 10.1007/s13361-014-0864-5

53) S. Milić, J. Bogdanović Pristov, D. Mutavdžić, A. Savić, M. Spasić, I. Spasojević. The relationship of physicochemical properties to the antioxidative activity of free amino acids in Fenton system. Environ. Sci. Technol. 49: 4245-4254, 2015. doi: 10.1021/ es5053396

54) K. Y. C. Lee, J. Majewski, T. L. Kuhl, P. B. Howes, K. Kjaer, M. M. Lipp, A. J. Waring, J. A. Zasadzinski, G. S. Smith. Synchrotron X-ray study of lung surfactant-specific protein SP-B in lipid monolayers. Biophys. J. 81: 572-585, 2001. 
55) S. Enami, M. R. Hoffmann, A. J. Colussi. Simultaneous detection of cysteine sulfenate, sulfinate, and sulfonate during cysteine interfacial ozonolysis. J. Phys. Chem. B 113: 9356-9358, 2009. doi: 10.1021/jp904316n

56) I. Spasojević, J. Bogdanović Pristov, L. Vujisić, M. Spasić. The reaction of methionine with hydroxyl radical: Reactive intermediates and methanethiol production. Amino Acids 42: 2439-2445, 2012. doi: 10.1007/s00726-011-1049-1

57) W. A. Pryor, R. M. Uppu. A kinetic-model for the competitive reactions of ozone with amino-acid-residues in proteins in reverse micelles. J. Biol. Chem. 268: 3120-3126, 1993.

58) M. R. M. Domingues, P. Domingues, A. Reis, C. Fonseca, F. M. Amado, A. J. Ferrer-Correia. Identification of oxidation products and free radicals of tryptophan by mass spectrometry. J. Am. Soc. Mass Spectrom. 14: 406-416, 2003. doi: 10.1016/ S1044-0305(03)00127-2

59) Z. Maskos, J. D. Rush, W. H. Koppenol. The hydroxylation of tryptophan. Arch. Biochem. Biophys. 296: 514-520, 1992. doi: 10.1016/0003-9861(92)90605-V

60) A. P. Willard, D. Chandler. Instantaneous liquid interfaces. J. Phys. Chem. B 114: 1954-1958, 2010. doi: 10.1021/jp909219k

61) M. D. Baer, C. J. Mundy. Toward an understanding of the specific ion effect using density functional theory. J. Phys. Chem. Lett. 2: 1088-1093, 2011. doi: 10.1021/jz200333b

62) S. Enami, L. A. Stewart, M. R. Hoffmann, A. J. Colussi. Superacid chemistry on mildly acidic water. J. Phys. Chem. Lett. 1: 3488-3493, 2010. doi: 10.1021/jz101402y

63) B. Fiser, B. Jójárt, I. G. Csizmadia, B. Viskolcz. Glutathione-hy- droxyl radical interaction: A theoretical study on radical recognition process. PLoS One 8: e73652, 2013. doi: 10.1371/journal. pone. 0073652

64) B. Breiten, M. R. Lockett, W. Sherman, S. Fujita, M. Al-Sayah, H. Lange, C. M. Bowers, A. Heroux, G. Krilov, G. M. Whitesides. Water networks contribute to enthalpy/entropy compensation in protein-ligand binding. J. Am. Chem. Soc. 135: 15579-15584, 2013. doi: 10.1021/ja4075776

65) V. Gupta, K. S. Carroll. Sulfenic acid chemistry, detection and cellular lifetime. Biochim. Biophys. Acta 1840: 847-875, 2014. doi: 10.1016/j.bbagen.2013.05.040

66) K. G. Reddie, K. S. Carroll. Expanding the functional diversity of proteins through cysteine oxidation. Curr. Opin. Chem. Biol. 12: 746-754, 2008. doi: 10.1016/j.cbpa.2008.07.028

67) L. Turell, H. Botti, S. Carballal, G. Ferrer-Sueta, J. M. Souza, R. Durán, B. A. Freeman, R. Radi, B. Alvarez. Reactivity of sulfenic acid in human serum albumin. Biochemistry 47: 358-367, 2008. doi: $10.1021 /$ bi701520y

68) T. Nakamura, T. Yamamoto, M. Abe, H. Matsumura, Y. Hagihara, T. Goto, T. Yamaguchi, T. Inoue. Oxidation of archaeal peroxiredoxin involves a hypervalent sulfur intermediate. Proc. Natl. Acad. Sci. U.S.A. 105: 6238-6242, 2008. doi: 10.1073/ pnas.0709822105

69) M. Sarker, J. Rose, M. McDonald, M. R. Morrow, V. Booth. Modifications to surfactant protein B structure and lipid interactions under respiratory distress conditions: Consequences of tryptophan oxidation. Biochemistry 50: 25-36, 2011. doi: 10.1021/ bi101426s 